\title{
Banking Crises and Market Discipline in Indonesian Banking Industry
}

\author{
George Adam Sukoco Sikatan ${ }^{1}$, Rokhim Rokhim ${ }^{*}$ \\ ${ }^{1}$ Department of Management, Faculty of Economics and Business, Universitas Indonesia, \\ West Java, 16424, Indonesia \\ *Corresponding author: rofikoh.rokhim@ui.ac.id
}

\begin{abstract}
This study analyzes the effect of banking crises towards market discipline in Indonesia. This study uses two periods of crisis in Indonesia, which are banking crisis in 1997/1998 and banking crisis in 2008. The dependent variable is market discipline; while bank risks are the independet variables (insolvency, liquidity, and credit risks). The control variables are banking level (the percentage savings of the customer, bank's size, bank's overhead costs, and Lerner index); industrial level (banking concentration level, the bank development); and macroeconomic variables (the growth of the real gross domestic product and inflation rate). The variables examined by the Generalized Method of Moments (GMM). This study finds a fact that on average market discipline weakens after Indonesia's banking crisis in 1997/1998. On the contrary, this study found a fact that market discipline strengthens after Indonesia's banking crisis in 2008. Eventually, this study finds a fact that there is no difference in market discipline between the domestic bank and foreign bank after Indonesia's banking crisis in 2008.
\end{abstract}

Keywords: Banking crises; market discipline; bank risk taking; Indonesia.

\begin{abstract}
ABSTRAK
Penelitian ini menguji dampak krisis perbankan terhadap market discipline di Indonesia, Penelitian ini menggunakan dua periode krisis perbankan di Indonesia yaitu tahun 1997/1998 dan tahun 2008. Variabel dependen adalah market discipline, sedangkan risiko perbankan merupakan variabel independen yang meliputi insolvency, likuiditas dan risiko kredit. Variabel kontrol terdiri dari level perbankan (tingkat tabungan pelanggan, ukuran bank dan beban overhead bank, Lerner index), level industry (level konsentrasi bank dan bank development), dan variabel-variabel ekonomi makro yang terdiri dari tingkat pertumbuhan produk domestic bruto riil dan tingkat inflasi. Variabel penelitian diuji menggunakan Generalized Method of Moments (GMM). Hasil penelitian menunjukkan bahwa secara rata-rata market discipline melemah setelah krisis perbankan di Indonesia tahun 1997/1998. Disisi lain penelitian ini menemukan bahwa market discipline menguat setelah krisis perbankan tahun 2008. Penelitian ini juga menemukan bahwa tidak ada perbedaan market discipline antara bank-bank domestik dan bank-bank asing paska krisis perbankan tahun 2008 di Indonesia.
\end{abstract}

Kata kunci: Krisis perbankan, market discipline, bank risk taking, Indonesia.

\section{INTRODUCTION}

The monetary crisis that has occurred in Asia has had a bad influence on the financial system and has caused a banking crisis in various countries. The banking crisis started by the financial liberalization marked by the gradual influx of foreign currency in the banking sector. The liberalization has increased the flow of foreign capital to Asian countries that at that moment were experiencing positive economic growth. The increase of foreign funds was then used as capital on high-yield projects. These funds were placed as credits with high risks. These decisions show that an adverse selection has happened (Hahm and Mishkin, 2000). Mishkin (1999) also found that the banking crisis that has happened in Asia started by the behavior of the banks that do not show bankers behaviors by not being careful, not honest and taking decisions too fast. When the economy in 
the Asian region declines and the banking interest rate increases, this would pressurize the risktakers'(speculators) abilities to return their debts so that the banking sector is threatened by the reduction of their assets quality. These actions by the banks and risk-takers render a big contribution to the disastrous situation of the domestic currency and banking crisis in Asia, including in Indonesia.

If analyzed further the market discipline level in Asian countries can be suspected as still being weak and be one of the primary causes of the banking crisis in Asia. The market discipline can be defined as a situation where the depositors punish the bank by requesting a higher interest rate or they will withdraw their money from that bank (Cubillas , et al., 2012). Actually, when a country has a good market discipline level, the banks tend to show banker behaviors and minimize speculative acts by the speculators.

Starting with Thailand in July 1997, this crisis has a contagion effect and brought a large impact on the conversion rate, stock exchange, and other asset prices in several Asian countries including Indonesia. Until July 1997, almost all people predicted that Indonesia will be very little affected by the crisis. As a consideration, at the time the economic foundation of Indonesia showed a low inflation rate, a trading surplus of more than USD 900millions, a large foreign currency reserve, more than USD 20 billion, a very good performance of the banking sector (Bank Indonesia, 2010). But who expected that one month after that the economy in Indonesia would also be affected. The mistake started when the investment funds in Indonesia were used. At that time Indonesia used short term loans for financing long-term projects. This meant that the debt repayments had to take place in a short time, while the profits will be obtained after a long time. Moreover, this nonprudent attitude of the banks in Indonesia in disbursing the credits to non-credible parties also caused this crisis to occur. Starting with the downfall of the Rupiah conversion rate to the US Dollar, many banks started to experience losses, especially banks that owe money in foreign currency and did not protect themselves sufficiently. Unstable conversion rates with additional worsening of banks' cash flow caused banks to encounter liquidity problems. This caused many banks lost the confidence of the public so that the public withdrew their money in large amounts. Many banks had to close down with the consequence that the economy became paralyzed.

Considering the main cause of the banking crisis that occurred in Asia and Indonesia the researchers conducted a research on the market condition before and after the crisis. This research is important to be conducted because Indonesia is a "bank based" country whereby the money circulation is $70 \%$ through banks. A thorough understanding of the Indonesian market condition can minimize the occurrence of a banking crisis that could be destructive for the entire Indonesian economy.

Moreover, this research was conducted because facts showed that a majority of the previous studies showed evidence of the weakening of the market after the banking crisis. If connected with the main factor of the Asian crisis whereby the market situation was weak, this fact could not be accepted. In fact, this market discipline situation should have improved after the banking crisis in order to avoid another banking crisis to reoccur, but facts have been found by earlier research just the opposite.

Haddad et al. (2011) in his research had analyzed the change in the deposit guarantee scheme and capital regulation at Indonesian banks during the banking crisis that happened in 1997-1998. They found the adoption of the "blanket guarantee" scheme which weakened the market condition. Other investigations regarding the banking crisis impact were conducted by Cubillas et al (2012). They analyzed the effects of the banking crisis on the market discipline situation by using an international sample of these banks. This writes up shows that on the average the market discipline situation weakened after the banking crisis. In the meantime, Demiguc-Kunt and Huizinga (2004) in their research using an international database of the banks in 51 countries showed that the explicit deposit insurance caused the depositors' wish to monitor the banks becoming very small and weakening the market discipline situation level. The cheaper the deposit insurance, the greater the weakening of the market. On the other hand, Peria and Schmukler (2001) conducted a research involving three countries samples, i.e. Argentine, Cile and Mexico during the period of 1980-1990. They found facts that the depositors punished the banks for their risky behavior, by withdrawing their deposits and asking for higher interest rates. The market disciplinary situation became more important after the crisis and the deposit warranty did not appear to reduce the market condition.

This research was conducted to support the BCBS regulation (Based Committee on Banking Supervision) in July 2004 together with the revised edition of June 2006 to produce the Basel II formation i.e. capital requirement to strengthen the performance and maintain the stability of banks globally. There are three main pillars in Basel II, i.e. capital requirement, official supervision and market discipline. The global crisis that happened at the time forced the policy makers, banking institutions, depositors as well as other parties 
involved to improve all factors when a bank took risks. As an example when Gueyie and Lai (2003) stated that discipline factors that affect the bank's decision to take risks include disciplining the regulation, disciplining by the bank itself and the market discipline.

The market discipline, in general, were agreed upon by the regulators and academicians to limit the bank risks that always varies and prevent a banking crisis (Cubillas, et al, 2012). The research conducted by the study was focused on the variation of the market discipline level in Indonesia at the time a banking crisis having a systemic effect in 1997-1998 happened and a crisis without systemic effects in 2008 (Laeven and Valencia 2012). This research sees how the relationship was between the banking risks and the cost of bank deposit changes after the banking crisis.

By considering that the number of studies regarding the impact of the market discipline towards the banking crisis were still small and how important it was to know the relationship between the banking crisis and the expected high market discipline level can prevent a crisis and maintain the banking stability as well as speed up the recovery so that this study would be attracted to conduct this research. Through this research, it was expected that a systematic proof regarding the banking crisis towards the market discipline level in Indonesia could be provided.

\section{Theory Framework}

Peria and Schmukler (2001) in their research researched three countries, namely Argentine, Chile and Mexico during 1980 and 1990. They found the facts that the depositors would punish the banks for their risky attitude, by withdrawing their deposits and require a higher interest rate. The market discipline level became more important after the crisis and the deposit warranty did not appear to reduce the market discipline level.

Then another research by Hadad et al (2011) that analyzed the changes in the deposit warranty scheme and capital regulation on Indonesian banks during the banking crisis that happened in the years 1997-1998. They found that the adoption of the "blanket guarantee" scheme weakened the market discipline level. Other research regarding the effect of the banking crisis on the market discipline was conducted by Cubillas, et al (2012), they analyzed the effect of the banking crisis on the market discipline by using an international sample of the banks. That study showed that on the average the market discipline weakened after the banking crisis.

If looked upon from the research result, it can be said that the previous research was not yet conclusive whereby several types of research found facts that the market discipline level weakened after the banking crisis and moreover, concluded the facts that the market discipline level strengthened after the banking crisis. In addition, from the majority of the previous studies, it could be observed that the market discipline level is the primary cause of the previous banking crisis in Asia and Indonesia which had caused the level weakening after the banking crisis. If it is connected with the Indonesian situation, there had been no research conducted regarding the impact of the 2008 banking crisis on the market discipline level. That is why this study would like to know whether the banking crisis weakened or strengthened the market discipline level in Indonesia.

The hypothesis formed was as followed:

$\mathrm{H}_{1}$ : The banking crisis of 1997/1998 has a significant effect on the market discipline level in Indonesia.

$\mathrm{H}_{2}$ : The banking crisis of 2008 has a significant effect on the market discipline level in Indonesia.

Looking at the previous research conducted by Cubillas, et al (2012) and Haddad, et al (2011), this study has not yet found a research about the effects of the banking crisis on the market discipline level for the two crisis periods. This study was interested in performing this research, because it connected to the Indonesian situation, between the first crisis and the second crisis. This study suspected a regulation change and market psychology has happened that would influence the market discipline level during those two periods. As an example, in the year 2006, a change has occurred on the blanket guarantee to become a limited blanket guarantee that this study suspected would cause a difference of the market discipline level regarding the two crisis periods. Based on that, a hypothesis formed was:

$\mathrm{H}_{3}$ : No market discipline level difference in Indonesia had occurred after the 1997/1998 banking crisis and the banking crisis of 2008 .

The research conducted by Haddad et al. (2011)which analyzed the change in the deposit guarantee scheme and capital regulation for banks in Indonesia during the banking crisis that happened in 1997-1998 found facts that the adoption of the blanket guarantee scheme weakened the market discipline level. Moreover, they also found facts that the market discipline works better with foreign banks than domestic banks. Based on the study of Haddad et al (2011), this study considered that the banking ownership affected the presence and market discipline. This study suspected that 
the market discipline level would be better with foreign banks than domestic banks. The reason is that foreign banks were supervised by both foreign and domestic regulators, and that is why foreign banks must have a better management than domestic banks. The following were the hypothesis that was formed:

$\mathrm{H}_{4}$ : No difference regarding the market discipline level after the banking crisis between foreign banks and domestic banks in Indonesia.

\section{RESEARCH METHOD}

\section{Data and Sampling Process}

Data used in the research were secondary data gathered from several sources. Banks financial level data were obtained from the Bank Indonesia library. Data were used to measure the macro variables taken from the World Bank website (www.worldbank.org) and IMF website (www. imf.org).

Data that would be processed in this research was the unbalanced panel data because the number of bank samples used every year were different. In order to test the banking crisis impact in the years 1997/1998 towards the market discipline level, this research used a sample from 1994-2007. In addition, for the impact of the banking crisis of 2008 on the market discipline level, this research used the sample of the years 19992011. This study used all of the banks in Indonesia as a sample.

\section{Operational Variables Definition}

\section{Dependent variable}

This study followed Peria and Schmukler (2001), Demirguc-Kunt and Huizinga (2004), Haddad et al. (2011) and Cubillas et al. (2012) that tested the market discipline by analyzing whether the depositor punished the risky bank by requesting higher interest rates. The dependent variable was the deposits' cost for the bank at year $t$ $\left(\operatorname{COSTD}_{i t}\right)$. This was measured by the annual interest ratio towards the total deposit.

\section{Independent variable}

Regarding this research, this study followed Cubillas, et al (2012) and Haddad, et al (2011) whereby they used the lagged dependent variable $\operatorname{COSTD}_{i t-1}$. With this variable, this study would like to see whether the deposit cost at present was affected by the previous period. In addition, this study followed Peria and Schmukler (2001) and Haddad, et al. (2011) whereby they considered three types of bank risks: insolvency, liquidity, and credit risks.
This study followed Laeven and Levine (2009) as well as Haddad et al. (2011) who used the proxy Z-score bank (Z-SCORE) as the proxy for the bank insolvency. Higher Z-score showed that the banking condition was more stable because of its inverse relationship with the possible bank insolvency. Because Z-score was highly skewed, the researcher had to use natural logarithm of the Z-score, which is normally distributed. Z-SCORE was calculated with an asset return level (ROA) and added with the capital asset ratio divided by the standard deviation of the asset return. This study used the current assets ratio to the total assets (LIQUIDITY) as a proxy for the liquidity risk as performed by Demirguc-Kunt and Huizinga (2004) and Hadad et al. (2011). This study used the ratio of the set-aside credit loss with the total gross credit (LLP) as a proxy for credit risks, this ratio is used among others by Gropp, et al. (2004) as well as Nier and Baumann (2006).

\section{Controlled Variable}

This study is following Cubillas et al.(2012) included banking level variables, industrial level variables and macroeconomic variables as control variables. Banking level variables were defined by the percentage savings of the customer (CUSTOMERD), bank assets size (SIZE), overhead costs (OVERHEAD), and Lerner index (LERNER). While for the industrial level variable as the control variable, this study referred to Beck, et al (2006), Fonseca and Gonzales (2010), and Hadad, et al (2011) that used the banking concentration level (CONC) and the bank development proxy (PRIVATECRED). Finally, for the macroeconomic variables, this study used the growth of the real gross domestic product (GDPGR) and inflation rate (INFLATION) as the control variable.

CUSTOMERD was measured by the total ratio of customer's savings towards the total compulsory interest. The researcher used this variable to control the banking deposit percentage that generally was guaranteed and not so sensitive towards the market discipline.

SIZE was measured by the natural logarithm of the total banking assets. The researcher controlled the influence for several reasons. On one side, the savings at certain banks were maybe large with lower costs if the hypothesis "too big to fail" would happen. The depositor believed that they would be compensated by the regulator if a problem arose and they had a lower risk as an impact of an augmentation of the diversification of their asset portfolio (Park and Peristiani, 1998). However on the other side, larger banks could pay larger fixed deposit interest rates compared to the smaller banks if they had a better investment 
choice or they were willing to be more intensively competitive with smaller banks (Rosen. 2007).

OVERHEAD was defined as the non- interest bank's burden divided by the assets. The difference in OVERHEAD can catch the difference in the work level or wages as well as a mixture of a banking product and service quality. A larger expenditure can be associated with a less efficient bank performance and thereby decrease the deposit's banking interest, in accordance with the traditional efficient-structure hypothesis (Berger and Hannan, 1989). But the expenditure ratio to the total assets could also be connected with a better service to the customer. If we could control the service quality, we could expect that the noninterest expenditure increase obtained a positive effect on the interest rate (Cubillas, et al, 2012).

LERNER, as a banking competitive variable, was a proxy to measure the banking market strength, defined as the difference between the price and the marginal costs expressed asa percentage of the price. Like Hadad et al (2011), the researcher did not predict a clear sign for LERNER because the bank can use a bigger market strength to pay a lower interest for their deposit, but they can also use to pay a higher interest rate to continue strengthening their market.

Referring to Beck, et al. (2006), Fonseca and Gonzales (2010), and Hadad, et al. (2011), CONC was used as a market structure variable, whereby CONC was a proxy for the bank concentration level, and defined as a fraction of the three largest banks as part of the assets of all public banks in our sample. Moreover, PRIVATECRED was used as a proxy for a development bank level, and calculated with a "private credit by deposit money banks and other financial institutions over GDP".

Finally, this study included the macroeconomic characteristics as the control variable. We follow Demigurc-Kunt and Huizinga (2004) and Hadad, et al (2011) and control for the growth of the real PDB (GDPGR) and the inflation rate (INFLATION).

\section{Statistic Method}

This study applied the Generalized Method of Moments (GMM) estimator developed for a dynamic data panel model by Arellano and Bond (1991) as performed by Hadad, et al (2011), Naceur and Omran (2011), Herrero, et al (2009), Albertazzi and Gambacorta (2009), Athanasoglou, et al, (2008) as well as Dietrich and Wanzenried (2010) to study the variation between the banking risks and the banking deposit costs after the banking crisis.

Several reasons this study chose this method were: first, this research used the unbalanced panel data. Second, there was an autoregressive process in the data regarding the deposit cost behavior (namely, the need for a dependent lagging model to catch the dynamic characteristics of the deposit costs). The third was the possibility of an endogeneity at the clarifying variable as well as the possessions of certain banks that were unknown, whereby it could be eliminated by conducting "first difference" on all variables.

The main model used for this research was the model that had been used by Cubillas et al. (2012):

$$
\begin{aligned}
\operatorname{COSTD}_{i t}= & \beta_{0}+\beta_{1} \operatorname{COSTD}_{i t-1}+\beta_{2} \mathrm{RISK}_{i t}+ \\
& \beta_{3} \mathrm{CRISIS}_{i t}+\beta_{4} \mathrm{RISK}_{i t} \mathrm{XCRISIS}_{i t}+ \\
& \beta_{5} \mathrm{BANK}_{i t}+\beta_{6} \mathrm{MACRO}_{i t}+ \\
& \sum_{\mathrm{t}=1990}^{2011} \mathrm{Tt}+\mu_{i}+\epsilon_{i t}
\end{aligned}
$$

COSTD $_{i t}$ constituted the deposit costs for bank $i$ for year $t$. RISK $i t$ constituted a collection of three risk proxies for bank $i$ for year $t$ (ZSCORE, LIQUIDITY, and LLP). CRISIS $i t$ constitutes a dummy variable that took a value of 1 for one year after the banking crisis and zero for the period before the crisis. RISK $_{i t} \mathrm{X} \mathrm{CRISIS}_{i t}$ constituted a variable that understood the change in the market discipline after the banking crisis. RISK $i t \mathrm{X}$ CRISIS $_{i t}$ constituted a variable that caught the market discipline change after the banking crisis. Bank $_{i t}$ constituted the controlling vector of the banking level variable and industrial variable. $\mathrm{MACRO}_{t}$ constituted the vector of the macroeconomic variable. While $\sum_{t=1990}^{2011}$ Tt constituted a dummy variable set to catch all bank-invariant time effects that was not included in the $\mu_{\mathrm{i}}$ regression and constituted an unobservable bankspecific effect and $\epsilon_{i t}$ constituted a white noise error. In the above model specification $\beta_{2}$ measures the market discipline level prior to the crisis, and $\beta_{4}$ caught the change inside after the banking crisis occurred. Because of the higher values on ZSCORE and LIQUIDITY showed a lower level of banking risk, the presence of the market discipline at the period before the crisis would be shown the negative coefficient for these variables (Cubillas et al, 2012; Hadad et al, 2011). Weakening or the increase of the market discipline after the banking crisis would be caught by $\beta_{4}$, which meant a negative coefficient or positive for the interaction between two proxies, namely the banking risk and the crisis dummy variable. Because LLP was relatively positive towards the banking crisis, the coefficient interpretation of this variable would become the opposite of what had been explained by ZSCORE and LIQUIDITY. 
Table 1. Descriptive Statistics.

\begin{tabular}{lccccccc}
\hline & Obs & Mean & Maximum & Minimum & Std. Dev. & Jarque-bera & Probability \\
\hline COSTD & 1,965 & 0.108860 & 2.404033 & 0.003553 & 0.114056 & $83,6315.5$ & 0.000000 \\
ZSCORE & 1,965 & 2.468475 & 6.261288 & -3.097473 & 1.231411 & 17,61818 & 0.000149 \\
LIQUIDITY & 1,965 & 0.965629 & 0.998761 & 0.852843 & 0.025568 & $1,053.579$ & 0.000000 \\
LLP & 1,965 & 0.062168 & 1.683092 & 0.000000 & 0.102657 & $232,961.1$ & 0.000000 \\
CUSTOMERD & 1,965 & 0.830436 & 0.993861 & 0.024555 & 0.182689 & $1,720.490$ & 0.000000 \\
SIZE & 1,965 & 14.18900 & 20.00809 & 9.766751 & 1.920393 & 73.73743 & 0.000000 \\
OVERHEAD & 1,965 & 0.018587 & 0.192041 & 0.000756 & 0.011845 & $120,229.7$ & 0.000000 \\
LERNER & 1,965 & 0.458824 & 0.963216 & -2.212755 & 0.222676 & $16,358.37$ & 0.000000 \\
CONC & 1,965 & 0.428727 & 0.569505 & 0.356510 & 0.053899 & 199.1287 & 0.000000 \\
PRIVATECRED & 1,965 & 32.35134 & 53.52872 & 17.19195 & 13.13892 & 208.5680 & 0.000000 \\
GDPGR & 1,965 & 0.044556 & 0.084000 & -0.131000 & 0.043615 & $12,157.06$ & 0.000000 \\
INFLATION & 1,965 & 0.145861 & 0.753000 & 0.055000 & 0.145519 & $16,884.91$ & 0.000000 \\
\hline
\end{tabular}

The dependent variable is the cost of deposit (COSTD). It was measured by the annual interest ratio towards the total deposit. For Independent variables, we include one lag of the dependent variable (LAG COSTD). Furthermore, this study includes ZSCORE, LIQUIDITY, and LLP are alternative bank risk measures as independent variables. ZSCORE is calculated with an asset return level (ROA) and added with the capital asset ratio divided by the standard deviation of the asset return. LIQUIDITY is the ratio of liquid assets to total assets. LLP is the ratio of loan loss provisions to total gross loans. CRISIS constitutes a dummy variable that took a value of 1 for one year after the banking crisis and zero for the period before the crisis. CUSTOMERD was the total ratio of customer's savings towards the total compulsory interest. SIZE is the natural logarithm of the total assets. OVERHEAD is defined as the non- interest bank's burden divided by the total assets. LERNER is defined as the difference between the price and the marginal costs expressed as a percentage of the price. CONC was a proxy for the bank concentration level, and defined as a fraction of the three largest banks as part of the assets of all public banks in our sample. PRIVATECRED is calculated with a "private credit by deposit money banks and other financial institutions over GDP". GDPGR is the annual growth rate of real GDP per capita. INFLATION is the annual inflation rate from the GDP deflator. The sample period is 1994-2011.

Table 2. Correlation Matrix

\begin{tabular}{|c|c|c|c|c|c|c|c|c|c|c|c|}
\hline & $C$ & $\begin{array}{c}\text { LIQUIDI } \\
\text { TY }\end{array}$ & LLP & $\begin{array}{l}\text { CUSTO } \\
\text { MERD }\end{array}$ & SIZE & $\begin{array}{l}\text { OVER } \\
\text { HEAD }\end{array}$ & $\begin{array}{l}\text { LER } \\
\text { NER }\end{array}$ & $\mathrm{CO}$ & $\begin{array}{l}\text { PRIVATE } \\
\text { CRED }\end{array}$ & GD & $\begin{array}{c}\text { INFLATI } \\
\text { ON }\end{array}$ \\
\hline & 00000 & 06575 & -0.28611 & 0.189 & 0.038 & 0.03435 & 26277 & & & & -0.1 \\
\hline & & & & & & & & & & & \\
\hline & & & & & & & & & & & \\
\hline & & -0 & & 0 & & & 7 & & & & \\
\hline & & 0.45782 & & & & & & & & & .12053 \\
\hline & & -0.31 & & & & & 40 & & & & 01634 \\
\hline & & 0.17513 & & -0.03607 & & & 100000 & & & & -0.16940 \\
\hline & & -0.13390 & & -0.02090 & & & -0.29188 & & & & -0.08319 \\
\hline & & -0. & & -0. & & & 76 & & 00 & & 0.29902 \\
\hline & & & & & & & & & & & -0.91506 \\
\hline 10 & 379 & -0.07573 & 0.24690 & 0.00400 & -0.12053 & 0.01634 & -0.16940 & -0.08319 & 0.29902 & -0.91506 & 1.00000 \\
\hline
\end{tabular}

The dependent variable is the cost of deposit (COSTD). It was measured by the annual interest ratio towards the total deposit. For Independent variables, we include one lag of the dependent variable (LAG COSTD). Furthermore, this study includes ZSCORE, LIQUIDITY, and LLP are alternative bank risk measures as independent variables. ZSCORE is calculated with an asset return level (ROA) and added with the capital asset ratio divided by the standard deviation of the asset return. LIQUIDITY is the ratio of liquid assets to total assets. LLP is the ratio of loan loss provisions to total gross loans. CRISIS constitutes a dummy variable that took a value of 1 for one year after the banking crisis and zero for the period before the crisis. CUSTOMERD was the total ratio of customer's savings towards the total compulsory interest. SIZE is the natural logarithm of the total assets. OVERHEAD is defined as the non- interest bank's burden divided by the total assets. LERNER is defined as the difference between the price and the marginal costs expressed as a percentage of the price. CONC was a proxy for the bank concentration level, and defined as a fraction of the three largest banks as part of the assets of all public banks in our sample. PRIVATECRED is calculated with a "private credit by deposit money banks and other financial institutions over GDP'. GDPGR is the annual growth rate of real GDP per capita. INFLATION is the annual inflation rate from the GDP deflator. The sample period is 1994-2011. 
Table 3. Regression Results

\begin{tabular}{|c|c|c|}
\hline $\begin{array}{c}\text { Dependent Variable }=\text { COSTD } \\
\text { Independent Variables }\end{array}$ & Crisis Period 1997-1998 & Crisis Period 2008 \\
\hline LAG COSTD & $\begin{array}{l}0.09528^{* * * *} \\
(0.000)\end{array}$ & $\begin{array}{c}-2.33680^{* * *} \\
(0.018)\end{array}$ \\
\hline ZSCORE & $\begin{array}{c}-0.00240 \\
(0.992)\end{array}$ & $\begin{array}{c}0.05377^{*} \\
(0.073)\end{array}$ \\
\hline LIQUIDITY & $\begin{array}{l}-6.70592^{* *} \\
(0.017)\end{array}$ & $\begin{array}{c}-2.75280 \\
(0.269)\end{array}$ \\
\hline LLP & $\begin{array}{l}16.62653^{* *} \\
(0.040)\end{array}$ & $\begin{array}{c}-0.12698 \\
(0.319)\end{array}$ \\
\hline ZSCORE XCRISIS & $\begin{array}{c}0.00499 \\
(0.985)\end{array}$ & $\begin{array}{c}-0.12400^{* *} \\
(0.038)\end{array}$ \\
\hline LIQUIDITYXCRISIS & $\begin{array}{c}5.28492^{*} \\
(0.079)\end{array}$ & $\begin{array}{c}-2.11317 \\
(0.867)\end{array}$ \\
\hline LLPXCRISIS & $\begin{array}{l}-16.42473^{* *} \\
(0.042)\end{array}$ & $\begin{array}{c}2.29172 \\
(0.185)\end{array}$ \\
\hline CUSTOMERD & $\begin{array}{c}-0.22468^{* *} \\
(0.013)\end{array}$ & $\begin{array}{c}-0.06544^{* * *} \\
(0.009)\end{array}$ \\
\hline SIZE & $\begin{array}{l}0.38568^{* * *} \\
(0.000)\end{array}$ & $\begin{array}{c}0.07331 \\
(0.316)\end{array}$ \\
\hline OVERHEAD & $\begin{array}{l}35.99287^{* * * *} \\
(0.000)\end{array}$ & $\begin{array}{l}20.11706^{* *} \\
(0.013)\end{array}$ \\
\hline LERNER & $\begin{array}{l}-0.28264^{* * * *} \\
(0.000)\end{array}$ & $\begin{array}{l}-0.56418^{* * * *} \\
(0.006)\end{array}$ \\
\hline CONC & $\begin{array}{l}2.68749^{* * * *} \\
(0.000)\end{array}$ & $\begin{array}{l}3.45036^{* *} \\
(0.019)\end{array}$ \\
\hline PRIVATECRED & $\begin{array}{l}-0.01001^{* * * *} \\
(0.000)\end{array}$ & $\begin{array}{c}0.01835^{* *} \\
(0.033)\end{array}$ \\
\hline GDPGR & $\begin{array}{l}-2.15636^{* * * *} \\
(0.000)\end{array}$ & $\begin{array}{c}2.80903 \\
(0.164)\end{array}$ \\
\hline INFLATION & $\begin{array}{l}0.80935^{* * * *} \\
(0.001)\end{array}$ & $\begin{array}{c}0.41286^{*} \\
(0.074)\end{array}$ \\
\hline
\end{tabular}

This table presents the result from Arrelano and Bond (1991) one-step GMM difference estimator for panel data. The dependent variable is the cost of deposit (COSTD). It was measured by the annual interest ratio towards the total deposit. For Independent variables, we include one lag of the dependent variable (LAG COSTD). Furthermore, this study includes ZSCORE, LIQUIDITY, and LLP are alternative bank risk measures as independent variables. ZSCORE is calculated with an asset return level (ROA) and added with the capital asset ratio divided by the standard deviation of the asset return. LIQUIDITY is the ratio of liquid assets to total assets. LLP is the ratio of loan loss provisions to total gross loans. CRISIS constitutes a dummy variable that took a value of 1 for one year after the banking crisis and zero for the period before the crisis. CUSTOMERD was the total ratio of customer's savings towards the total compulsory interest. SIZE is the natural logarithm of the total assets. OVERHEAD is defined as the non- interest bank's burden divided by the total assets. LERNER is defined as the difference between the price and the marginal costs expressed as a percentage of the price. CONC was a proxy for the bank concentration level and defined as a fraction of the three largest banks as part of the assets of all public banks in our sample. PRIVATECRED is calculated with a "private credit by deposit money banks and other financial institutions over GDP". GDPGR is the annual growth rate of real GDP per capita. INFLATION is the annual inflation rate from the GDP deflator.

* Indicate statistical significance at the $10 \%$ level.

**Indicate statistical significance at the $5 \%$ level.

$* * *$ Indicate statistical significance at the $1 \%$ level.

\section{RESULTS AND DISCUSSION}

Based on the result of the above Table 3 it can be seen that the banking crisis in Indonesia during the period of 1997/1998 had caused a weakening of the market discipline level in Indonesia. This could be proven by comparing the variables that understood that a market discipline prior to the crisis
(ZSCORE, LIQUIDITY and LLP). The significant influence of the LIQUIDITY variable which had a negative sign and LLP which had a positive sign showed the existence of a market discipline prior to the banking crisis. Furthermore, the significant influence of the variable LIQUIDITYXCRISIS which had a positive sign and LLPXCRISIS that had a negative sign was consistent with the theory 
that a sensitivity reduction of the bank deposit costs towards the banking risks. This result was consistent with Cubillas, et al. (2012), Hadad, et al (2011) and Demirguc- Kunt and Huizinga (2004). At the three prior studies, the explicit guarantee from the government towards the savings was strongly believed as the main reason for the weakening of the market discipline.

In the meantime based on the above data processing, it could be concluded that the banking crisis that occurred in Indonesia during the period of 2008 had caused the market discipline level in Indonesia to increase. The significant influence of the ZSCORE variable having a positive sign indicated the absence of a market discipline prior to the banking crisis. Then the significant effect of the ZSCOREXCRISIS variable having a negative sign which was consistent with the theory that a sensitivity augmentation had occurred off the deposit costs to the banking risks after the banking crisis. This result was consistent with Peria and Schmukler (2001) who had held a research on three countries, i.e. Argentine, Chile and Mexico from 1980- 1990. They found the fact that the depositor would penalize the banks for their risky behavior, by withdrawing their deposits and requesting a higher interest rate. The market discipline became more important after the crisis.

The negative sign of the CUSTOMERD variable during the crisis period of 1997/1998 and 2008 showed that the banks paid an average of lower interest rate for warrantied savings (Cubillas, et al., 2012). In addition, the positive sign of the variable SIZE during the crisis period of 1997-1998 was consistent with the statement that larger banks had a bigger choice to own a better investment and compete more intensively compared to smaller banks. Then the positive sign of the OVERHEAD variable on the regression result during the crisis period of 1997/1998 and 2008 showed that the banks were not efficient in their operation. The negative sign of the variable LERNER on both regressions was consistent with Hadad et al (2011), whereby the market used a stronger market strength to pay a lower interest rate on the customer's savings.

Then the positive sign on the variable CONC showed that the market concentration level influenced the bank deposit interest rate, where for more concentrated industries the saving's interest rate would augment. The regression output of the PRIVATECRED variable during the crisis period of 1997/1998 showed that the higher development level of the banks would reduce the cost of fund of these banks. On the other side, the result of the PRIVATECRED regression variable in 2008 showed that the larger banking development increased the cost of fund of this bank.

The negative sign on the variable GDPGR on the regression output during the crisis period of 1997/1998 showed the facts that the higher economic growth decreased the bank's cost of fund. Finally, the positive sign of the inflation variable on both regression results showed that when inflation increased the cost of the fund will also increase.

From the above data analysis result, the hypothesis of this research was answered. From the data processing result, it could be concluded that the banking crisis that happened in Indonesia, both in 1997/ 1998 and in 2008 had a significant effect towards the banking crisis. The banking crisis of 1997/1998 had caused the weakening of the market discipline level in Indonesia. Consequently, this research accepted the first hypothesis $\left(H_{1}\right)$ and the second hypothesis $\left(H_{2}\right)$ which stated that the banking crisis of $1997 / 1998$ and the banking crisis of 2008 had a significant impact towards the market discipline level in Indonesia.

Further, the regression result conducted by the researcher also found the fact, that the market discipline level was different in Indonesia after the banking crisis of $1997 / 1998$ and 2008. At the banking crisis that happened in 1997/1998, the facts were found that there was a weakening of the market discipline level in Indonesia. On the other hand at the banking crisis of 2008 facts were found that there was a strengthening of the market discipline level in Indonesia. Therefore, it could be concluded that this research disapproves the third hypothesis $\left(H_{3}\right)$, which meant that there was a market discipline level difference in Indonesia after the banking crisis of 2008. During the 1997/1998 crisis the Indonesian government was still using the full blanket guarantee scheme, however, for the 2008 crisis, the Indonesian government had already used the limited blanket guarantee. The policy difference in the banking customers' warranty was strongly suspected to become the main factor of causing the result difference at the $1997 / 1998$ crisis as well as the 2008 crisis. This result was consistent with the findings of Cubillas, et al. (2012), Haddad et al. (2011) as well as Demirguc-Kunt and Huizinga (2004). Those studies encountered the fact that government's explicit warranty towards the savings, and crisis handling policy, which had an accommodative nature, had caused the weakening of the market discipline after the banking crisis. 
Table 4. Regression Results for Domestic Bank and Foreign Bank in Indonesia

\begin{tabular}{|c|c|c|c|c|}
\hline \multirow{2}{*}{$\begin{array}{c}\text { Dependent Variable }=\text { COSTD } \\
\text { Independent Variables }\end{array}$} & \multicolumn{2}{|c|}{ Crisis Period 1997-1998 } & \multicolumn{2}{|c|}{ Crisis Period 2008} \\
\hline & Domestic Bank & Foreign Bank & Domestic Bank & Foreign Bank \\
\hline \multirow[t]{2}{*}{ LAG COSTD } & $0.08044^{* * * *}$ & -0.10601 & $-2.58537 * *$ & 0.00363 \\
\hline & $(0.001)$ & $(0.133)$ & $(0.016)$ & $(0.957)$ \\
\hline \multirow[t]{2}{*}{ ZSCORE } & -0.02492 & -0.04658 & $0.09313^{*}$ & -0.00156 \\
\hline & $(0.928)$ & $(0.470)$ & $(0.079)$ & $(0.696)$ \\
\hline \multirow[t]{2}{*}{ LIQUIDITY } & $-6.97062^{* * *}$ & 1.40361 & -4.27262 & $1.13615^{*}$ \\
\hline & $(0.008)$ & $(0.431)$ & $(0.173)$ & $(0.098)$ \\
\hline \multirow[t]{2}{*}{ LLP } & $16.21422^{* *}$ & -1.19558 & 0.03787 & -0.00811 \\
\hline & $(0.038)$ & $(0.601)$ & $(0.672)$ & $(0.637)$ \\
\hline \multirow[t]{2}{*}{ ZSCORE XCRISIS } & 0.01014 & 0.05242 & $-0.18975^{* *}$ & $0.01245^{* *}$ \\
\hline & $(0.971)$ & $(0.413)$ & $(0.018)$ & $(0.036)$ \\
\hline \multirow[t]{2}{*}{ LIQUIDITYXCRISIS } & $6.58150^{* *}$ & -1.24306 & 0.07129 & $-6.18955^{*}$ \\
\hline & $(0.027)$ & $(0.425)$ & $(0.995)$ & $(0.087)$ \\
\hline \multirow[t]{2}{*}{ LLPXCRISIS } & $-15.83887^{* *}$ & 1.16924 & 2.30668 & -0.28940 \\
\hline & $(0.041)$ & $(0.609)$ & $(0.197)$ & $(0.158)$ \\
\hline \multirow[t]{2}{*}{ CUSTOMERD } & $-0.21179 * *$ & $-0.17059^{* * *}$ & $-0.06750^{* * *}$ & $-0.15638^{* * *}$ \\
\hline & $(0.038)$ & $(0.000)$ & $(0.009)$ & $(0.007)$ \\
\hline \multirow[t]{2}{*}{ SIZE } & $0.383039 * * *$ & 0.00968 & 0.11017 & 0.00902 \\
\hline & $(0.000)$ & $(0.334)$ & $(0.216)$ & $(0.447)$ \\
\hline \multirow[t]{2}{*}{ OVERHEAD } & $36.33125^{* * *}$ & $2.84640^{* * * *}$ & $19.94362^{* *}$ & $3.02978^{* *}$ \\
\hline & $(0.000)$ & $(0.005)$ & $(0.011)$ & $(0.010)$ \\
\hline \multirow[t]{2}{*}{ LERNER } & $-0.25223^{* * *}$ & $-0.16519^{* * *}$ & $-071615^{* * *}$ & $-0.12521^{* * *}$ \\
\hline & $(0.000)$ & $(0.000)$ & $(0.001)$ & $(0.002)$ \\
\hline \multirow[t]{2}{*}{ CONC } & $2.71646^{* * * *}$ & $0.18863^{* * *}$ & $4.20928^{* *}$ & -0.02191 \\
\hline & $(0.000)$ & $(0.004)$ & $(0.018)$ & $(0.801)$ \\
\hline \multirow[t]{2}{*}{ PRIVATECRED } & $-0.00912^{* * *}$ & $4.62 \mathrm{e}-06$ & $0.01876^{* *}$ & -0.00146 \\
\hline & $(0.000)$ & $(0.995)$ & $(0.040)$ & $(0.207)$ \\
\hline \multirow[t]{2}{*}{ GDPGR } & $-2.08970^{* * *}$ & $-0.38577^{*}$ & 2.96102 & $-1.15691^{* * *}$ \\
\hline & $(0.000)$ & $(0.094)$ & $(0.203)$ & $(0.005)$ \\
\hline \multirow{2}{*}{ INFLATION } & $0.82000^{* * * *}$ & 0.06485 & $0.61032^{* * *}$ & 0.06651 \\
\hline & $(0.000)$ & $(0.160)$ & $(0.060)$ & $(0.139)$ \\
\hline
\end{tabular}

This table presents the result from Arrelano and Bond (1991) one-step GMM difference estimator for panel data. The dependent variable is the cost of deposit (COSTD). It was measured by the annual interest ratio towards the total deposit. For Independent variables, we include one lag of the dependent variable (LAG COSTD). Furthermore, the researcher includes ZSCORE, LIQUIDITY, and LLP is alternative bank risk measures as independent variables. ZSCORE is calculated with an asset return level (ROA) and added with the capital asset ratio divided by the standard deviation of the asset return. LIQUIDITY is the ratio of liquid assets to total assets. LLP is the ratio of loan loss provisions to total gross loans. CRISIS constitutes a dummy variable that took a value of 1 for one year after the banking crisis and zero for the period before the crisis. CUSTOMERD was the total ratio of customer's savings towards the total compulsory interest. SIZE is the natural logarithm of the total assets. OVERHEAD is defined as the non- interest bank's burden divided by the total assets. LERNER is defined as the difference between the price and the marginal costs expressed as a percentage of the price. CONC was a proxy for the bank concentration level and defined as a fraction of the three largest banks as part of the assets of all public banks in our sample. PRIVATECRED is calculated with a "private credit by deposit money banks and other financial institutions over GDP". GDPGR is the annual growth rate of real GDP per capita. INFLATION is the annual inflation rate from the GDP deflator.

* Indicate statistical significance at the $10 \%$ level.

** Indicate statistical significance at the 5\% level.

*** Indicate statistical significance at the $1 \%$ level.

From Table 4, it could be seen that the sign and significant influence on the variable LIQUIDITY (-) with a p-value of 0.08 and LLP (+) with a $p$-value of 0.38 showed the market discipline presence at domestic banks before the banking crisis of 1997/1998 in Indonesia. Meanwhile if we look at the sign and significant influence of the variable LIQUIDITYXCRISIS (+) with a $p$-value of 0.027 and LLPXCRISIS (-) with a p-value of 0.041which showed a decline in the deposit cost sensitivity towards the banking risks after the banking risks at the domestic bank, as a negative influence of LIQUIDITY on the banking deposit costs and the positive influence of LLP towards the banking risks. Based on the above facts it could be concluded that a weakening of the market discipline at domestic banks in Indonesia happened after the banking crisis of 1997/1998. While for the 
data processing result for the foreign bank the writer could not find a conclusive proof, this was caused due to the absence of a significant independent variable.

While for the banking crisis of 2008 , for the above model it could be seen that the sign and significant effect on the variable ZSCORE $(+)$ with a p-value of 0.079 showed us the absence of market discipline for domestic banks prior to the 2008banking crisis in Indonesia. Further, if we observe the sign and significant influence of the variable ZSCOREXCRISIS (-) with a p-value of 0.018 , it showed there was an increase of the deposit costs sensitivity towards the banking risks after the banking crisis on the domestic bank, as a positive influence of ZSCORE on the bank deposit costs. Based on the above facts it can be concluded that an increase of the market discipline on domestic banks in Indonesia happened after the banking crisis of 2008. Further, for foreign banks in 2008 could be seen that the signs and significant impact on the variable LIQUIDITY $(+)$ with a $p$ value of 0.098 showed the absence of the market discipline on foreign banks before the banking crisis of 2008 in Indonesia. In the mean time when we see the sign and significant influence of the variable LIQUIDITY X CRISIS (-) with a p-value of 0.087 it showed an increase of the deposit costs sensitivity towards the banking risks after the banking crisis on foreign banks, as a positive influence of LIQUIDITY on the bank deposit costs.

From the above analysis, the result showed that a weakening of the market discipline on domestic banks occurred after the banking crisis of 1997/ 1998. This study did not find a conclusive result towards the foreign banks because all independent variables that detected a market discipline level were not significant. These insignificant results were suspected due to the insufficient total number of samples. So that, during the crisis period of 1997/1998 the writer could not answer the fourth hypothesis $\left(H_{4}\right)$.

While at the 2008 crisis facts were found that an augmentation of the market discipline after the banking crisis both for domestic banks and foreign banks occurred, which meant answering and accepting the fourth hypothesis $\left(H_{4}\right)$ namely there were no differences between the market discipline level after the banking crisis of 2008 between foreign banks and domestic banks in Indonesia. This result was opposite to what was found by Hadad, et al (2011) that conducted the research using the crisis period of 1997/1998, whereby at this research it was found that the market discipline level for foreign banks was better compared to domestic banks.

\section{Robust Examination}

In order to check the robustness of our results, the regression was run without some independent variable and explanatory variable which highly correlated. LIQUIDITY and SIZE were excluded because of their strong correlation. After the deletion of those variables, this study found the basic results did not change. Furthermore, a regression was run with static panel data procedures, using both fixed and random effects and find the basic results did not change. The study uses all of the bank in Indonesia as a sample.

\section{CONCLUSION}

This study summarized that the banking crisis of 1997/1998 had a significant influence on the market discipline level in Indonesia where the crisis weakened the market discipline level in Indonesia. On the other hand, the banking crisis of 2008 had a significant influence towards the market discipline level in Indonesia, whereby this crisis strengthened the market discipline level in Indonesia. The difference in these results maybe because of the previous research Indonesia was still using the "full blanket guarantee" system, while regarding the research conducted by the writer in 2008 Indonesia was already using the "limited blanket guarantee" scheme. Moreover, this research found also facts that there was a weakening of the market discipline on domestic banks after the banking crisis of 1997/1998, but the writer did not find a conclusive result on foreign banks because all independent variables identified a market discipline level which was not significant. While at the crisis of year 2008, facts were found that a strengthening of the market discipline happened after the banking crisis, both on domestic banks and foreign banks. It was implied that there was no difference in the market discipline level after the banking crisis of 2008 between foreign banks and domestic banks in Indonesia.

For further studies, this research could be extended by investigating what factors influenced the change in the market discipline level after a banking crisis. Moreover, the researcher could further conduct a trans-national research and enter a limited blanket guarantee savings scheme using a degradation based on the risks that could be applied in Indonesia in 2015.

This results suggested the banks to be more prudent in minimizing the occurrence of a banking crisis. The banks are expected to be able to manage the insolvency risks, liquidity risks and credit risks that they own. The result of the strengthening of the market discipline after the banking crisis of 
2008 showed that the depositors were already concerned towards the banks' behavior so that the banks had to show the banker behaviors, such as prudent, honest and the process in taking firm decisions.

For the regulators, these research results were expected to enable them to take a decision or policy that increase the market discipline, such as the strengthening of the banking industry supervision. In addition, the regulator was expected to be able to apply the regulation Basel III and savings guarantee scheme limited blanket guarantee with degradation based on the immediate risk in order to create a healthy world banking condition and prevent a crisis to happen.

For the depositor, it was expected that the depositor can be more concerned towards the risky banking behavior in order to minimize a banking crisis to happen and an incident that would create losses to bank customers.

\section{REFERENCES}

Albertazzi, U., and Gambacorta, L. (2009). Bank profitability and the business cycle. Journal of Financial Stability, 5, 393-409.

Arellano, M., and Bond, S. (1991). Some test of specification for panel data: Monte Carlo evidence and application to employment equations. Review of Economic Studies, 58, 227-297.

Athanasoglou, P.P., Brissimis, S.N., and Delis, M.D. (2008). Bank-specific, Industry-specific and macroeconomic determinants of bank profitability. Journal of International Financial Markets, Institutions and Money, 18, 121136.

Bank Indonesia. (2010). Krisis Keuangan Global dan Penyelamatan Sistem Perbankan Indonesia, Jakarta.

Beck, T., Demirgüç-Kunt, A., and Maksimovic, V. (2006). The influence of financial and legal institutions on firm size. Journal of Banking and Finance, 30, 2995-3015.

Berger, A., Hannan, T.H., 1989. The price-concentration relationship in banking. The Review of Economics and Statistics, 71, 291-299.

Cubillas, E., Fonseca, A.R., and González, F. (2012). Banking crises and market discipline: international evidence. Journal of Banking and Finance 36, 2285-2298.

Demirgüç-Kunt, A., Huizinga, H. (2004). Market discipline and deposit insurance. Journal of Monetary Economics, 51, 375-399.
Dietrich, A., and Wanzenried, G. (2010). Determinants of bank profitability before and during the crisis: evidence from Switzerland. Journal of International Financial Markets, Institutions, and Money, 21, 307-327.

Fonseca, A.R., and González, F., 2010. How bank capital vary across countries: the influence of cost of deposits, market power and bank regulation. Journal of Banking and Finance, 34, 892-902.

Herrero, G., Gavilá, S., and Santabárbara, D. (2009). What explains the low profitability of Chinese banks? Journal of Banking \& Finance, 33, 2080-2092.

Gropp, R., Jukka, V., and Vulpes, G. (2004). Market indicators, bank fragility, and indirect market discipline. EconWPA: Finance 0411015

Gueyie, J.-P., and Lai, V.S. (2003). Bank moral hazard and the introduction of official deposit insurance in Canada. International Review of Economics and Finance, 12, 247-273.

Hadad, M.D., Agusman, A., Monroe, G.S., Gasbarro, D., and Zumwalt, J.K. (2011). Market discipline, financial crisis and regulatory changes: evidence from Indonesian banks. Journal of Banking and Finance 35, 15521562.

Hahm, J., and Mishkin, F.S. (2000). Causes of the Korean financial crisis: lessons for policy. NBER Working Papers, 7483.

Laeven, L., and Levine, R. (2009). Bank governance, regulation and risk taking. Journal of Financial Economics, 93, 259-275.

Laeven, L., and Valencia, F. (2012). Systemic banking crises: an update. IMF Working Paper No. $12 / 163$.

Mishkin, F.S. (1999). Lessons from the Asian crisis. Journal of International Money and Finance, 18, 709-723.

Naceur, S.B., and Omran, M. (2011). The effects of bank regulations, competition, and financial reforms on banks' performance. Emerging Market Review, 12, 1-20.

Nier, E., and Baumann, U. (2006). Market discipline, disclosure and moral hazard in banking. Journal of Financial Intermediation, 15, 332361.

Park, S., and Peristiani, S. (1998). Market discipline by thrift depositors. Journal of Money, Credit, and Banking, 30, 347-364.

Peria, M.S., and Schmukler, S.L. (2001). Do depositors punish banks for bad behavior?. Journal of Finance, 56, 1029-1051.

Rosen, R.J. (2007). Banking market conditions and deposit interest rates. Journal of Banking and Finance, 31, 3862-3884. 